\title{
Detachment efficiency of fruits from coffee plants subjected to mechanical vibrations ${ }^{1}$
}

\author{
Andre Luiz de Freitas Coelho², Fábio Lúcio Santos ${ }^{3}$, \\ Francisco de Assis de Carvalho Pinto ${ }^{4}$, Daniel Marçal de Queiroz ${ }^{4}$
}

\section{ABSTRACT}

The development of efficient machines for the mechanical harvesting of coffee plants requires the use of appropriate vibrational parameters. Thus, in order to detach less unripe fruits and decrease reharvesting, branch breakage and defoliation, it is important to choose the appropriate frequency, amplitude and vibration time. This study aimed at analyzing the detachment efficiency of fruits from coffee plants according to vibrational parameters and ripening stage. Fruit bunches were sampled at the green and mature stages and subjected to vibration, using a system composed by a signal generator, an amplifier and an electromagnetic vibrating machine. Tests combined different frequencies (16.4 Hz, 20.3 Hz, $24 \mathrm{~Hz}, 25.6 \mathrm{~Hz}, 30.0 \mathrm{~Hz}$ and $33.0 \mathrm{~Hz}$ ), amplitudes $(5.0 \mathrm{~mm}, 7.0 \mathrm{~mm}$ and $9.0 \mathrm{~mm})$ and vibration times (10.0 s and $20.0 \mathrm{~s})$. The vibration times did not affect the detachment efficiency. There was a trend for higher detachment efficiency in mature fruits than in green fruits. The detachment efficiency increased with increasing vibration frequency and amplitude.

KEY-WORDS: Coffea arabica; vibrational parameters; mechanical harvesting.

\section{INTRODUCTION}

Coffee is an important product for the Brazilian economy, being Brazil the largest worldwide producer, with an estimated production of 44.28 million $60-\mathrm{kg}$ bags, in 2015. The Minas Gerais State is the largest Brazilian producer (mainly Arabica coffee), followed by the Espírito Santo State (predominantly Conilon coffee) (Conab 2015).

Among the operations necessary for coffee cultivation, detachment requires the largest amount of labor. Mechanical harvesting has been considered

\section{RESUMO}

Eficiência de derriça de frutos de cafeeiro submetido a vibrações mecânicas

O desenvolvimento de máquinas eficientes para a colheita mecanizada do cafeeiro exige a utilização de parâmetros vibracionais adequados. Assim, para um menor desprendimento de frutos verdes, repasse, quebra de galhos e desfolha, devem ser utilizados magnitudes de frequência, amplitude e tempo de vibração adequados. Objetivou-se analisar a eficiência de derriça de frutos de cafeeiro, em função de parâmetros vibracionais e estádio de maturação. Cachos de frutos foram amostrados nos estádios de maturação verde e cereja e submetidos à vibração, utilizando-se um sistema composto por um gerador de sinais, um amplificador e uma máquina vibratória eletromagnética. Os ensaios foram realizados combinando-se diferentes frequências $(16,4 \mathrm{~Hz} ; 20,3 \mathrm{~Hz} ; 24 \mathrm{~Hz}$; $25,6 \mathrm{~Hz} ; 30,0 \mathrm{~Hz}$; e 33,0 Hz), amplitudes $(5,0 \mathrm{~mm}$; 7,0 mm; e $9,0 \mathrm{~mm}$ ) e tempos de vibração (10,0 s e $20,0 \mathrm{~s})$. Os tempos de vibração empregados não influenciaram na eficiência de derriça. Houve tendência de a eficiência de derriça dos frutos cerejas ser superior à dos frutos verdes. A eficiência de derriça aumentou à medida que se aumentou a frequência e a amplitude de vibração.

PALAVRAS-CHAVE: Coffea arabica; parâmetros vibracionais; colheita mecanizada.

an alternative to increase efficiency. Barbosa et al. (2005) observed that operational efficiency of portable harvesters is $251 \%$ higher than that for manual harvesting.

The mechanical harvesting of coffee and other crops like apricot, orange, pistachio, olive and grape has been accomplished by means of mechanical vibration. Starting from this principle, the kinetic energy is transmitted to the plant, or its parts, promoting the detachment of fruits (Erdogan et al. 2003, Sanders 2005, Sessiz \& Ozcan 2006, Souza et al. 2006, Polat et al. 2007, Pezzi \& Caprava 2009, Santos et al. 2010a).

1. Manuscript received in Jun./2015 and accepted for publication in Nov./2015 (http://dx.doi.org/10.1590/1983-40632015v4536227).

2. Faculdade de Viçosa, Centro de Ciências Exatas e Tecnológicas, Viçosa, MG, Brasil. E-mail: andrecoelho.mec@gmail.com.

3. Universidade Federal de Lavras, Departamento de Engenharia, Lavras, MG, Brasil.E-mail: fabio.santos@deg.ufla.br.

4. Universidade Federal de Viçosa, Departamento de Engenharia Agrícola, Viçosa, MG, Brasil. E-mails: facpinto@ufv.br, queiroz@ufv.br. 
An efficient mechanical harvesting of coffee includes a minimal detachment percentage of green fruits and low reharvesting, in addition to low defoliation and branch breakage. Detachment of green fruits is undesirable, since only fruits at the ripe stage have all the chemical characteristics necessary to get a good quality coffee (Fagan et al. 2011, Ságio 2012).

Reharvesting is usually performed manually, increasing the production cost (Oliveira et al. 2007a). Defoliation and branch breakage increase impurities in the coffee, reducing its quality. Moreover, they impair the plant structure, compromising the next production cycle (Souza et al. 2006).

Analysis of harvesting efficiency has been conducted with coffee and other crops, such as cherries, apricots, nuts and olives, using mechanical vibration (Erdogan et al. 2003, Mateev \& Kostadinov 2004, Sessiz \& Ozcan 2006, Polat et al. 2007). This type of analysis allows the establishment of the appropriate vibrational parameters for the design and operation of harvesting machinery.

After the analytical determination of natural frequencies for the first and second mode shapes of the fruit-stem system, Ciro (2001) conducted a detachment test on coffee branches with less than $50 \%$ of ripe fruits. Branches were subjected to unidirectional vibration at different frequencies $(24.66 \mathrm{~Hz}, 30.0 \mathrm{~Hz}$ and $36.66 \mathrm{~Hz}$ ), amplitudes $(5.0 \mathrm{~mm}, 10.0 \mathrm{~mm}$ and $15.0 \mathrm{~mm})$ and vibration time of $5 \mathrm{~s}$. The author found that the increase in the vibration frequency and amplitude improved the detachment efficiency of mature fruits. The highest degree of selectivity was observed when subjecting the branch to vibration at the natural frequency of the mature ripening stage $(24.66 \mathrm{~Hz})$, with smaller vibration amplitudes.

By assessing the detachment efficiency of coffee fruits, Santos et al. (2010a) tested three branch lengths $(5.0 \mathrm{~mm}, 10.0 \mathrm{~mm}$ and $15.0 \mathrm{~mm})$ (Catuaí and Mundo Novo varieties) subjected to mechanical vibration. Branches were subjected to vibrations with different frequencies $(13.33 \mathrm{~Hz}, 16.67 \mathrm{~Hz}, 20.00 \mathrm{~Hz}$, $23.33 \mathrm{~Hz}$ and $26.67 \mathrm{~Hz})$ and amplitudes $(3.75 \mathrm{~mm}$, $5.00 \mathrm{~mm}, 6.25 \mathrm{~mm}$ and $7.50 \mathrm{~mm}$ ), in two different directions (longitudinal and transversal). The authors concluded that the detachment efficiency was directly and positively related to the vibration frequency and amplitude.

Likewise, Guedes (2011) examined the detachment efficiency of coffee fruits using branches with length of 50-100 mm (Red Catuaí), in two harvest periods. Tests were performed with different vibration frequencies $(35 \mathrm{~Hz}, 40 \mathrm{~Hz}, 45 \mathrm{~Hz}$, $50 \mathrm{~Hz}$ and $55 \mathrm{~Hz}$ ) and amplitudes $(3.5 \mathrm{~mm}, 5.0 \mathrm{~mm}$ and $6.5 \mathrm{~mm}$ ). The author observed that vibration amplitude and frequency influenced the detachment efficiency. For the frequencies and amplitudes tested, there was a greater tendency for the detachment of mature fruits. In addition, the ripening stage influenced the detachment efficiency only at the end of the harvesting season, indicating the influence of the period on harvesting selectivity.

An efficient harvesting process requires an appropriate combination of vibration frequency, amplitude and duration. Even though the effects of vibration parameters on harvesting efficiency of coffee fruits have been investigated by several authors (Ciro 2001, Santos et al. 2010a and 2010b, Guedes 2011), there is no record in the literature on the effects of vibration time in the detachment efficiency for coffee harvested by mechanical vibrations.

This study aimed at evaluating the detachment efficiency of Catuaí coffee fruits, concerning ripening stage and vibration frequency, amplitude and time.

\section{MATERIAL AND METHODS}

The research was performed with Arabica coffee, Catuai Vermelho variety, in Viçosa, Minas Gerais State, Brazil, in May-July 2013. Branches with length of $30 \mathrm{~cm}$ were randomly collected from plants, in the morning, and fruits were harvested within a maximum of four hours. Samples were prepared by selecting the branches containing predominantly fruits at the green or ripe maturity stages, depending on the treatment.

To test harvesting by mechanical vibration, coffee branches were subjected to different combinations of frequencies and amplitudes. A system produced by Ling Dynamic Systems (LDS), comprised of a signal generator (Dactron COMET USB), an amplifier (LDS PA100E-CE) and an electromagnetic vibrating machine (V-406), was used.

The signal generator was controlled by a computer using the Catman ${ }^{\circledR}$ software, allowing the acquisition of pulse, random and sinusoidal vibration signals. The electrical vibration signals generated were sent to the amplifier, where they could be amplified tenfold. In the vibrating machine, the amplified electrical signals were converted into 
displacements from the mobile base by means of electromagnets (Table 1).

The system control was accomplished by a piezoelectric acceleration transducer (accelerometer) manufactured by $\mathrm{PCB}$, with a working range of $10-4,000 \mathrm{~Hz}$. Signals from this transducer allow the signal generator to precisely control the vibration frequency and amplitude imposed to the mobile base of the vibrating machine.

Branches were fixed to the attachment system, which was coupled to the mobile base that was joined to the piezoelectric acceleration transducer (Figure 1).

Tests were conducted by subjecting samples to excitation in the form of sinusoidal function, adopting the longitudinal vibration. The factors evaluated were the ripening stages and vibration frequencies, amplitudes and times (Table 2). Detachment efficiency was evaluated in a $2 \times 6 \times 3 \times 2$ factorial scheme (ripening stage $\mathrm{x}$ frequency $\mathrm{x}$ displacement amplitude $x$ vibration time), in a completely randomized experimental design, with three replications.

Table 1. Technical characteristics of the electromagnetic vibrating machine (Viçosa, Minas Gerais State, Brazil, 2013).

\begin{tabular}{lc}
\hline Dynamic range $(\mathrm{Hz})$ & $5-9,000$ \\
\hline Maximum load $(\mathrm{N})$ & 198 \\
\hline Maximum peak-to-peak displacements $(\mathrm{mm})$ & 17.6 \\
\hline Maximum acceleration $(\mathrm{g})$ & 100 \\
\hline
\end{tabular}
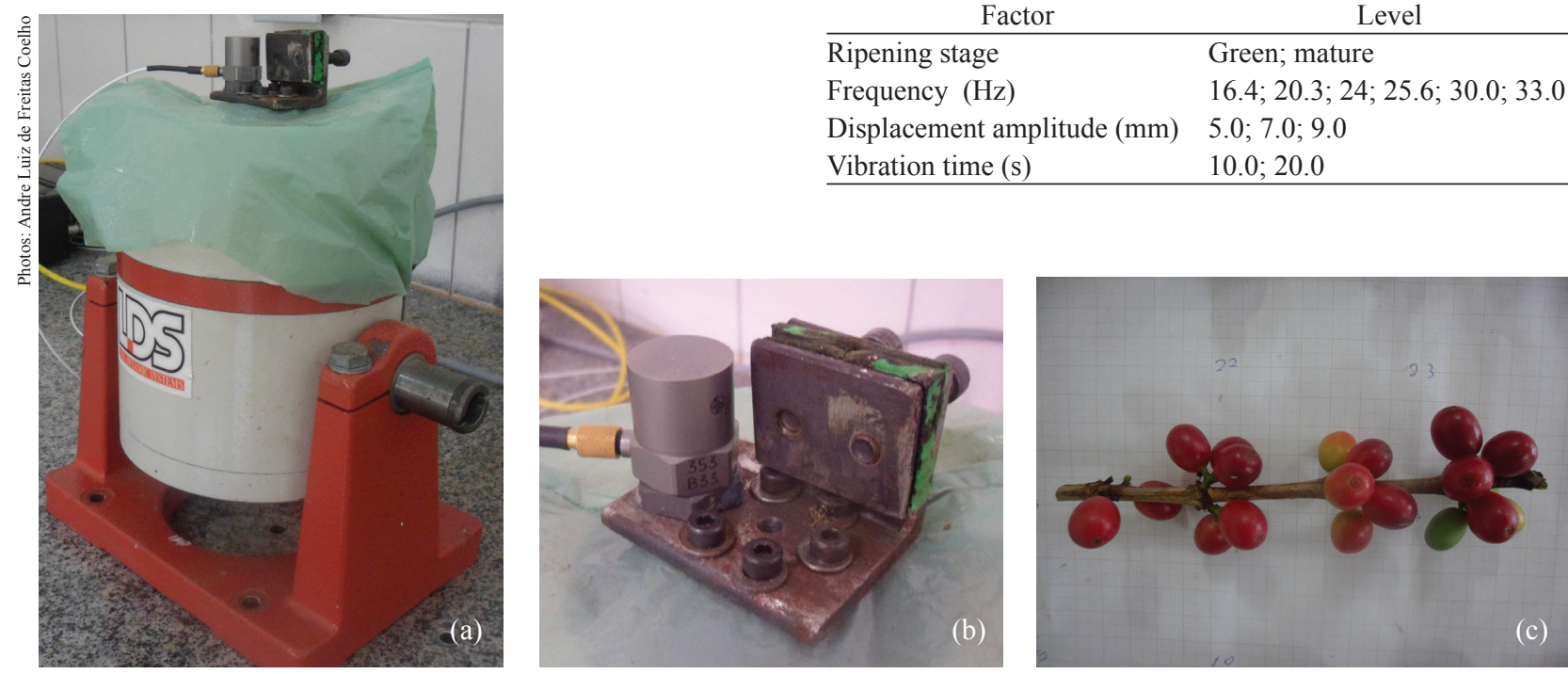

Figure 1. Vibrating machine (a), attachment system for samples (b) and a sample of coffee branch (c) (Viçosa, Minas Gerais State, Brazil, 2013). 
Breakdown of significant interactions was performed using the fat2.dic function of the ExpDes.pt package. Regression analysis was run using the response surface method from the rsm package (Lenth 2009).

\section{RESULTS AND DISCUSSION}

Triple and quadruple interactions were not tested in the analysis of variance due to the difficulty of analysis and interpretation of the physical behavior of the system based on the results.

Significant interactions were observed only between vibration frequency and amplitude and between amplitude and ripening stage (Table 3). The significant interaction between frequency and amplitude, also found by Santos et al. (2010a and 2010b) and Guedes (2011), indicates the importance of choosing the right combination for these factors on harvesting. On the other hand, the significant interaction between amplitude and ripening stage points to the possibility of a selective harvesting through the appropriate selection of vibration amplitude and frequency (Santos 2008).

In addition, non-significant interactions including the factor time demonstrate the lack of influence of time on the detachment efficiency. Average values for detachment efficiency were $6.34 \%$ and $5.03 \%$, respectively for the times of $10.0 \mathrm{~s}$ and $20.0 \mathrm{~s}$.

Nevertheless, Oliveira et al. (2007b) observed an increased harvesting efficiency with increasing time of exposure to vibration. This happens because the extended vibration time causes a greater number of displacements in the fruit-stem system, increasing

Table 3. Summary of analysis of variance (SAV) of the experiment for coffee detachment evaluation (Viçosa, Minas Gerais State, Brazil, 2013).

\begin{tabular}{lcc}
\hline \multicolumn{1}{c}{ SAV } & DF & MS \\
\hline Time (T) & 1 & $93.69^{\text {ns }}$ \\
Frequency (F) & 5 & $797.76^{*}$ \\
Amplitude (A) & 2 & $3,105.13^{*}$ \\
Ripening (R) & 1 & $2,164.10^{*}$ \\
T x F & 5 & $86.38^{\text {ns }}$ \\
T x A & 2 & $34.74^{\text {ns }}$ \\
T x R & 1 & $140.68^{\text {ns }}$ \\
F x A & 10 & $424.26^{*}$ \\
F x R & 5 & $183.79^{\text {ns }}$ \\
A x R & 2 & $1,016.22^{*}$ \\
\hline DF: degree of freedom; MS: mean square; * F significant at $5 \% ;{ }^{\text {ns }} \mathrm{F}$ non- \\
significant.
\end{tabular}

the probability of fruit detachment. Conversely, an increased vibration time reduces the operational capacity of the harvester, in addition to increasing damages to the plant structure, maybe causing defoliation and branch breakage (Souza et al. 2006, Oliveira et al. 2007b). The behavior observed in this study may be related to the frequencies and amplitudes used in the experiment, which were not suitable for fruit detachment, as evidenced by the low detachment efficiency obtained.

The evaluation of fruit detachment efficiency was performed by breaking down the significant interaction of ripening within the amplitude levels. For the amplitudes of $5.0 \mathrm{~mm}$ and $7.0 \mathrm{~mm}$, no significant differences were found for detachment efficiencies between ripening stages. For the amplitude of $9.0 \mathrm{~mm}$, the detachment efficiency was significantly higher for the mature ripening stage (Table 4).

For the three amplitudes analyzed, there was a trend toward increased detachment efficiency of fruit at the mature ripening stage. This result was also obtained by Ciro (2001), due to the lower rigidity of fruit stalk attachment to the stem at the mature ripening stage. The reduction in rigidity is related to the cell wall degradation in the stalks by enzymatic activity (Castro \& Marraccini 2006).

When breaking down the interaction of amplitude with ripening levels, significance was only observed for amplitudes within the mature ripening stage. In other words, the detachment efficiency was influenced by vibration amplitude only for this ripening stage.

A model to describe fruit detachment efficiency according to vibration amplitude, for the mature ripening stage, was obtained by regression analysis $\left[E_{f c}=-24.53+4.77 A\left(\mathrm{R}^{2}=85.59 \%\right)\right]$. The model selection was based on the significance of the equation coefficients and coefficient of determination (Table 5). Considering the linear regression model,

Table 4. Mean detachment efficiency (\%) according to the ripening stage and vibration amplitude (Viçosa, Minas Gerais State, Brazil, 2013).

\begin{tabular}{|c|c|c|c|}
\hline \multirow{2}{*}{ Ripening stage } & \multicolumn{3}{|c|}{ Amplitude (mm) } \\
\hline & 5.0 & 7.0 & 9.0 \\
\hline Green & $1.04 \mathrm{~A}$ & $0.69 \mathrm{~A}$ & $5.83 \mathrm{~A}$ \\
\hline Mature & $1.57 \mathrm{~A}$ & $4.33 \mathrm{~A}$ & $20.65 \mathrm{~B}$ \\
\hline
\end{tabular}


regardless of the vibration frequency used in the tests, there was an increased efficiency of mature fruit detachment with the increasing vibration amplitude.

The significant interaction between frequency and amplitude was evaluated by regression, using the response surface method (Table 6). Linear, cross and quadratic terms for frequency and amplitude were significant at $5 \%$, by the F-test.

Considering the significant interaction between vibration frequency and amplitude, a multiple regression model was fitted to describe the detachment efficiency as a function of vibration amplitude and frequency. The contribution of the quadratic terms was negligible, thus not added to the model:

$$
E f=37.81-7.26 A-2.13 F+0.41 F A\left(\mathrm{R}^{2}=29.53\right)
$$

where $E f=$ detachment efficiency (\%); $A=$ vibration amplitude (mm); and $F=$ vibration frequency $(\mathrm{Hz})$.

Detachment efficiency increased with increasing vibration frequency and amplitude (Figure 2), corroborating the results found in similar researches (Ciro 2001, Souza 2004, Oliveira 2009, Santos et al. 2010a and 2010b, Guedes 2011).

In the sections of the response surface, it was observed that the elevation in the detachment efficiency according to increasing vibration frequency

Table 5. Summary of analysis of variance (SAV) of breaking down the interaction of amplitude within the ripening stages (Viçosa, Minas Gerais State, Brazil, 2013).

\begin{tabular}{lrrrrr}
\hline \multicolumn{1}{c}{ SAV } & DF & \multicolumn{1}{c}{ SS } & \multicolumn{1}{c}{ MS } & \multicolumn{1}{c}{ F } & P-value \\
\hline A/R (M) & 2 & $7,650.09$ & $3,825.04$ & $28.01^{*}$ & $<0.001$ \\
A/R (G) & 2 & 592.61 & 296.30 & $2.17^{\text {ns }}$ & 0.117 \\
Residue & 210 & $28,676.42$ & 136.55 & & \\
Total & 215 & & & \\
* significant at $5 \%$; & ns non-significant. DF: degree of freedom; SS: sum of square; \\
MS: mean square; A: amplitude (mm); R: ripening; G: green; M: mature.
\end{tabular}

became progressively more significant with the increasing vibration amplitude (Figure 3 ).

Mean values of detachment efficiency were less than $30 \%$, in other words, the amount of vibrational energy and time of exposure were not sufficient for the efficient detachment of fruits. Thus, a single pass harvesting using such frequencies and amplitudes is not viable. On the other hand, Santos et al. (2010a) obtained a mean detachment efficiency

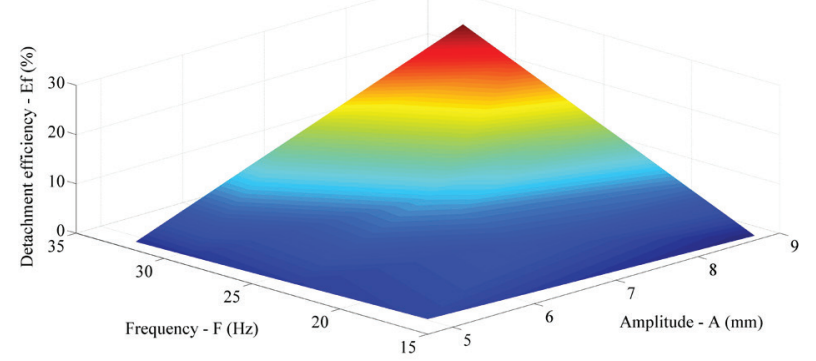

Figure 2. Fitted response surface of detachment efficiency according to vibration amplitude and frequency for Red Catuaí fruits (Viçosa, Minas Gerais State, Brazil, 2013).

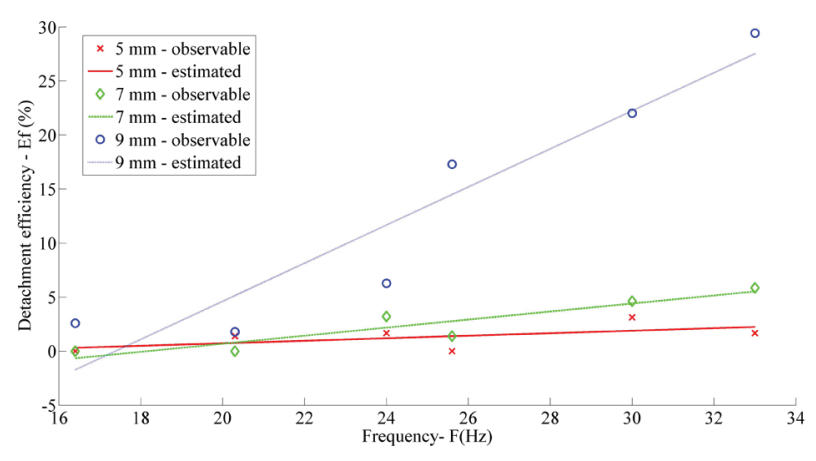

Figure 3. Detachment efficiency as a function of the vibration frequency for each vibration amplitude applied (Viçosa, Minas Gerais State, Brazil, 2013).

Table 6. Regression analysis of detachment (RAD) efficiency as a function of vibration amplitude and frequency (Viçosa, Minas Gerais State, Brazil, 2013).

\begin{tabular}{lrrrrr}
\hline \multicolumn{1}{c}{ RAD } & DF & \multicolumn{1}{c}{ SS } & MS & F & P-value \\
\hline F, A & 2 & $8,899.14$ & $4,449.57$ & $36.02^{*}$ & $<0.001$ \\
F $^{*}$ & 1 & $3,028.31$ & $3,028.31$ & $24.51^{*}$ & $<0.001$ \\
F, A & 2 & $1,214.24$ & 607.12 & $4.91^{*}$ & 0.008 \\
Lack of adjustment & 12 & $13,299.60$ & 108.30 & $0.87^{\text {ns }}$ & 0.578 \\
Pure error & 198 & $24,652.98$ & 124.51 & & \\
Residue & 210 & & & & \\
\hline
\end{tabular}

* significant at $5 \%$; ${ }^{\text {s }}$ non-significant. DF: degree of freedom; SS: sum of square; MS: mean square; F: frequency; A: amplitude. 
of $65.25 \%$, for a frequency of $26.67 \mathrm{~Hz}$, amplitude of $7.50 \mathrm{~mm}$ and vibration time of $15 \mathrm{~s}$, while Guedes (2011) found mean values of detachment efficiency below $50 \%$, for the frequency of $55 \mathrm{~Hz}$, amplitude of $3.25 \mathrm{~mm}$ and vibration time of $15 \mathrm{~s}$. Therefore, improved detachment efficiency can be achieved by increasing the vibration frequency, vibration amplitude or both.

\section{CONCLUSIONS}

1. For a certain vibration amplitude, the detachment efficiency of fruits at the mature ripening stage was higher than at the green stage.

2. Detachment efficiency increased with increasing vibration frequency and amplitude, since a greater amount of vibrational energy was provided to the fruits.

3. Frequencies and amplitudes applied resulted in low detachment efficiency (below 30\%) and, therefore, were not adequate for an efficient detachment of the samples tested.

\section{REFERENCES}

BARBOSA, J. A.; SALVADOR, N.; SILVA, F. M. Desempenho operacional de derriçadoras mecânicas portáteis, em diferentes condições de lavouras cafeeiras. Revista Brasileira de Engenharia Agrícola e Ambiental, Campina Grande, v. 9, n. 1, p. 129-132, 2005.

CASTRO, R. D.; MARRACCINI, P. Citology, biochemistry and molecular changes during coffee fruit development. Brazilian Journal of Plant Physiology, Campos dos Goytacazes, v. 18, n. 1, p. 175-199, 2006.

CIRO, H. J. Coffee harvesting: I. Determination of the natural frequencies of the fruit stem system in coffee trees. Applied Engineering in Agriculture, St. Joseph, v. 17, n. 4, p. 475-479, 2001.

COMPANHIA NACIONAL DE ABASTECIMENTO (Conab). Acompanhamento da safra brasileira: café, safra 2015, segunda estimativa, julho/2015. 2015. Disponível em: <http://www.conab.gov.br/conteudos. php? $a=1253 \& t>$. Acesso em: 21 jun. 2015.

ERDOGAN, D. et al. Mechanical harvesting of apricots. Biosystems Engineering, Bedford, v. 85, n. 1, p. 19-28, 2003.

FAGAN, E. B. et al. Efeito do tempo de formação do grão de café (Coffea sp.) na qualidade da bebida. Bioscience Journal, Uberlândia, v. 27, n. 5, p. 729-738, 2011.
GUEDES, D. M. Efeito da utilização de frequências de vibração na faixa de 35 a $55 \mathrm{~Hz}$ sobre a eficiência de derriça do café. 2011. 52 f. Dissertação (Mestrado em Engenharia Agrícola) - Universidade Federal de Viçosa, Viçosa, 2011.

LENTH, R. V. Response-surface methods in R using rsm. Journal of Statistical Software, Los Angeles, v. 32, n. 7, p. 1-17, 2009.

MATEEV, L. M.; KOSTADINOV, G. D. Probabilistic model of fruit removal during vibratory morello harvesting. Biosystems Engineering, Bedford, v. 87, n. 4, p. 425-435, 2004.

OLIVEIRA, E. et al. Custos operacionais da colheita mecanizada do cafeeiro. Pesquisa Agropecuária Brasileira, Brasília, DF, v. 42, n. 6, p. 827-831, 2007a.

OLIVEIRA, E. et al. Influência da vibração das hastes e da velocidade de deslocamento da colhedora no processo de colheita mecanizada do café. Revista Engenharia Agrícola, Jaboticabal, v. 27, n. 3, p. 714-721, 2007b.

OLIVEIRA, M. V. M. Desenvolvimento e avaliação de um dispositivo para derriça de café. 2009. 118 f. Dissertação (Mestrado em Engenharia Agrícola) - Universidade Federal de Viçosa, Viçosa, 2009.

PEZZI, F.; CAPRARA, C. Mechanical grape harvesting: investigation of the transmission of vibrations. Biosystems Engineering, Bedford, v. 103, n. 3, p. 281-286, 2009.

POLAT, R. et al. Mechanical harvesting of pistachio nuts. Journal of Food Engineering, Pullman, v. 79, n. 4, p. 1131-1135, 2007.

R DEVELOPMENT CORE TEAM. $R$ : a language and environment for statistical computing. Vienna: R Foundation for Statistical Computing, 2013.

SÁGIO, S. A. Análise molecular e fisiológica do etileno durante o amadurecimento de frutos de café. 2012. $116 \mathrm{f}$. Tese (Doutorado em Agronomia) - Universidade Federal de Lavras, Lavras, 2012.

SANDERS, K. F. Orange harvesting systems review. Biosystems Engineering, Bedford, v. 90, n. 2, p. 115-125, 2005.

SANTOS, F. L. Simulação e avaliação do comportamento dinâmico de frutos do cafeeiro na derriça. 2008. $136 \mathrm{f}$. Tese (Doutorado em Engenharia Agrícola) - Universidade Federal de Viçosa, Viçosa, 2008.

SANTOS, F. L. et al. Efeito da frequência e amplitude de vibração sobre a derriça de frutos de café. Revista Brasileira de Engenharia Agrícola e Ambiental, Campina Grande, v. 14, n. 4, p. 425-431, 2010a.

SANTOS, F. L. et al. Analysis of the coffee harvesting process using an electromagnetic shaker. Acta Scientiarum Agronomy, Maringá, v. 32, n. 3, p. 373-378, 2010 b. 
SESSIZ, A.; OZCAN, M. T. Olive removal with pneumatic branch shaker and abscission chemical. Journal of Food Engineering, Pullman, v. 76, n. 2, p. 148-153, 2006.

SOUZA, C. M. A. Desenvolvimento e modelagem de sistemas de derriça e de abanação de frutos do cafeeiro.
2004. 123 f. Tese (Doutorado em Engenharia Agrícola) Universidade Federal de Viçosa, Viçosa, 2004.

SOUZA, C. M. A.; QUEIROZ, D. M.; RAFULL, L. Z. D. Derriçadora portátil na colheita total e seletiva de frutos do cafeeiro. Pesquisa Agropecuária Brasileira, Brasília, DF, v. 41, n. 11, p. 1637-1642, 2006. 